\title{
Novel L284R MAPT Mutation in a Family with an Autosomal Dominant Progressive Supranuclear Palsy Syndrome
}

\author{
Jonathan D. Rohrer ${ }^{a}$ Dominic Paviour ${ }^{a, b}$ Jana Vandrovcova ${ }^{b} \quad$ John Hodges ${ }^{c}$ \\ Rohan de Silva ${ }^{b}$ Martin N. Rossor ${ }^{a}$ \\ ${ }^{a}$ Dementia Research Centre, Department of Neurodegenerative Disease, and beta Lila Weston Institute, \\ UCL Institute of Neurology, University College London, London, UK; ' Prince of Wales Medical Research Institute, \\ Randwick, N.S.W., Australia
}

\section{Key Words}

Frontotemporal dementia • Progressive supranuclear palsy · Tau

\begin{abstract}
Background: MAPT mutations are associated with disorders within the frontotemporal lobar degeneration spectrum. The usual presenting syndrome is behavioural variant frontotemporal dementia, although some patients present with parkinsonism. In a number of these cases the dominant clinical features have been consistent with a progressive supranuclear palsy (PSP) syndrome. Objective: To describe a family with an autosomal dominant PSP syndrome with a novel L284R mutation in the MAPT gene. Methods: A retrospective case review and genetic analysis of the MAPT gene. A literature review of PSP syndromes associated with mutations in the MAPT gene. Results: Multiple members of family DRC292 across different generations had a PSP syndrome with 1 member of the family being found to have a novel L284R mutation in the MAPT gene. Behavioural features were also prominent in most cases. A PSP syndrome is only a rare finding associated with MAPT mutations and many of these cases have atypical clinical features. Conclusion: Although rare,
\end{abstract}

MAPT mutations should be considered when there is an autosomal dominant family history of a PSP syndrome, particularly of young onset and with prominent behavioural features.

Copyright $\odot 2010$ S. Karger AG, Base

\section{Introduction}

Mutations in the MAPT gene are causative of neurodegenerative disorders in the frontotemporal lobar degeneration spectrum [1-3]. The majority of patients present with behavioural variant frontotemporal dementia (bvFTD), i.e. personality change and behavioural symptoms, although this may subsequently be associated with parkinsonism. However, some patients have a primary parkinsonian syndrome which can be a corticobasal syndrome or more rarely a progressive supranuclear palsy (PSP) syndrome $[4,5]$. Of the 44 pathogenic mutations in MAPT currently described (http://www.molgen.ua.ac. be/FTDMutations/) only 8 have been associated with a PSP syndrome [6-14]. We describe a novel L284R mutation in exon 10 of the MAPT gene in a family with an autosomal dominant PSP syndrome.

\section{KARGER}

(๑) 2010 S. Karger AG, Basel

Fax +4161306 1234

E-Mail karger@karger.ch

www.karger.com
Accessible online at:

www.karger.com/ndd
Prof. Martin N. Rossor

Dementia Research Centre, UCL Institute of Neurology

Queen Square

London WC1N 3BG (UK)

Tel. +44 207829 8773, Fax +44 207676 2066, E-Mail mrossor@ dementia.ion.ucl.ac.uk 


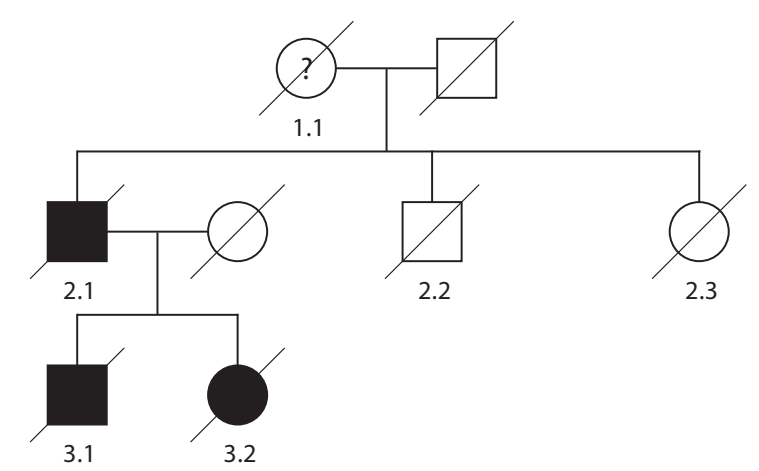

Fig. 1. Family tree of DRC292.

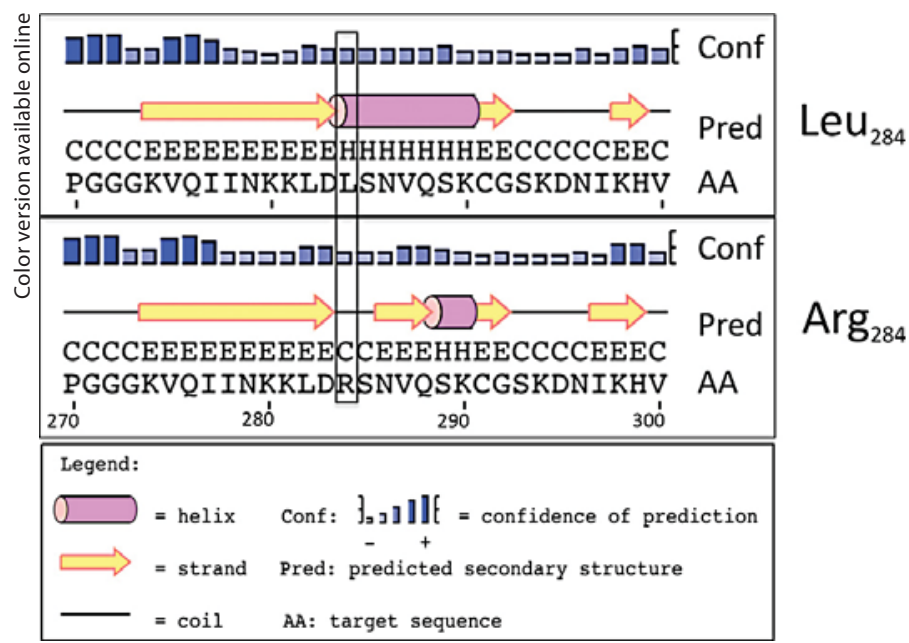

Fig. 2. Secondary structure predictions using PSIPRED (http:// bioinf.cs.ucl.ac.uk/psipred/). The non-conservative arginine substitution causes a reduction in the predicted $\alpha$-helical content $(\mathrm{H})$ of the region containing the residue.

\section{Results}

DRC292 is a Caucasian family from the South of England (fig. 1). Little history is available in previous generations of the family, although 1.1 became wheelchair bound in midlife and died at a young age. 2.1 developed problems in the early 40 s, in that the family noticed that the eyes had a staring quality and there was increasing difficulty judging distances. From the same time there were multiple falls and shortly afterwards a progressive dementing illness, followed by death at the age of 48 years. 3.1 developed a change in personality (particularly increased obsessiveness) in the mid-40s with falls from around the same time. 3.1 was subsequently diagnosed with PSP and became increasingly immobile and eventually mute, dying at the age of 52 years. 3.2 also developed a personality change at the age of 43 years with apathy and increased irritability as well as worsening memory for recent events and backward falls from around the same time. The neurological examination at the age of 45 years revealed a parkinsonian syndrome with increased tone in all 4 limbs. There was a full range of smooth pursuit eye movements but abnormal saccadic eye movements, particularly in the vertical plane. There was also difficulty with eyelid opening and a dysarthria. 3.2 was diagnosed with PSP at this assessment, deteriorating rapidly from this time with worsening mobility and dying 4 years after onset at the age of 47 years.

Patient 3.2 consented to donate a blood sample to a dementia genetics study investigating autosomal dominant dementia families [15] and was found to have a novel CTT $\rightarrow$ CGT mutation in exon 10 of the MAPT gene causing substitution of a leucine at position 284 with an arginine (L284R; numbering according to $2 \mathrm{~N} 4 \mathrm{R}$, the longest CNS isoform of tau). This mutation has not previously been reported, though the same codon is affected by the pathogenic silent L284L mutation (CTT $\rightarrow$ CT $\underline{C}$ ) which has been reported as causing a frontotemporal lobar degeneration syndrome with behavioural symptoms, executive dysfunction and memory impairment [16, 17]. L284R probably has the same effect as L284L, which affects a predicted A/C-rich splicing enhancer (ACE) and causes a strong shift to exon-10-containing (4R tau) transcripts [16]. However, L284R also causes a non-conservative change from the hydrophobic leucine to the polar, positively charged arginine (fig. 2). It is therefore possible that the mutation has the dual pathogenic effect of increased exon 10 inclusion combined with impaired microtubule binding and/or aggregation due to increased $\beta$-sheet content, as seen with the missense mutations. This mechanism may also apply to other exon 10 mutations (N279K, P301L/S, S305N) that have been associated with a clinical and pathological PSP or corticobasal syndrome phenotype [18]. Unfortunately, DNA was not available from other members of the family to investigate whether the mutation segregated with the presence of disease. 
Table 1. MAPT mutations causing a PSP-like syndrome

\begin{tabular}{|c|c|c|c|c|c|c|}
\hline R5L & Poorkaj et al. [8] & 1 & falls, dysarthria, micrographia & 62 & 5 & tau $4 \mathrm{R}>3 \mathrm{R}$ \\
\hline \multirow[t]{3}{*}{ N279K } & Delisle et al. [6] & 2 & parkinsonism, apathy, bradyphrenia & 40 & 7 & tau \\
\hline & & & attentional problems, apathy & 41 & N/A & $\mathrm{N} / \mathrm{A}$ \\
\hline & Tsuboi et al. [9] & N/A & report of 5 families with parkinsonism/supranuclear palsy & $41-45^{1}$ & $6-8.5^{1}$ & $\mathrm{~N} / \mathrm{A}$ \\
\hline \multirow{2}{*}{$\Delta \mathrm{N} 296$} & & & personality change, parkinsonism & 39 & 3 & N/A \\
\hline & Rossi et al. [11] & 1 & antecollis, dysarthria, falls, slowing of ocular movements & 36 & N/A & N/A \\
\hline P301L & Kaat et al. [14] & 1 & $\mathrm{~N} / \mathrm{A}$ & N/A & N/A & $\mathrm{N} / \mathrm{A}$ \\
\hline G303V & Ros et al. [12] & 3 & akinetic-rigid syndrome, falls, gaze palsy, dysarthria & 37 & 8 & tau $4 \mathrm{R}>3 \mathrm{R}$ \\
\hline S305S & & & dementia, apathy, language problems & 49 & 7 & $\mathrm{~N} / \mathrm{A}$ \\
\hline $10+3$ & Spina et al. [13] & 2 & postural imbalance, dizziness, stiff neck & $\mathrm{N} / \mathrm{A}$ & $\mathrm{N} / \mathrm{A}$ & $\mathrm{N} / \mathrm{A}$ \\
\hline $10+16$ & Morris et al. [10] & 1 & fatigue, apathy, micrographia, falls & 40 & 5 & tau \\
\hline
\end{tabular}

AAO = Age at onset; N/A = not available.

${ }^{1}$ Range of mean values in different families with the same mutation.

\section{Discussion}

DRC292 have an autosomal dominant PSP syndrome with early falls and a behavioural syndrome, an onset in the 40s and disease duration around 4-7 years. Reviewing previous descriptions of PSP syndromes associated with MAPT mutations (table 1), many of the cases in fact have had a fairly atypical PSP syndrome $[7,9,19,20]$ with a diagnosis of PSP (or atypical PSP) having been given to the patient because of the development of a supranuclear gaze palsy some time during the course of the illness usually in association with falls, parkinsonism and a dementia (usually of the bvFTD type). With this said, however, there are undoubtedly some patients reported who have a more typical PSP syndrome with few early features apart from gaze palsy or falls $[11,12]$. Although little information is available in the family reported here, they all appeared to present with early features of a PSP syndrome but also in some cases with behavioural and cognitive features consistent with bvFTD. In summary, a PSP syndrome is a rare manifestation of MAPT mutations, but screening should be considered in families where there is an autosomal dominant history of a PSP syndrome, particularly of young onset and when there are accompanying features suggestive of bvFTD.

\section{Acknowledgements}

This study was undertaken at the University College London Hospitals/University College London, which received a proportion of funding from the Department of Health's National Institute for Health Research Biomedical Research Centres funding scheme. The Dementia Research Centre is an Alzheimer's Research Trust Coordinating Centre. This study was also funded by the Medical Research Council, UK.

References

\footnotetext{
1 Hutton M, Lendon CL, Rizzu P, Baker M, Froelich S, Houlden H, Pickering-Brown S, Chakraverty S, Isaacs A, Grover A, Hackett J, Adamson J, Lincoln S, Dickson D, Davies P, Petersen RC, Stevens M, de Graaff E, Wauters E, van Baren J, Hillebrand M, Joosse M, Kwon JM, Nowotny P, Heutink P: Association of missense and $5^{\prime}$-splice-site mutations in tau with the inherited dementia FTDP-17. Nature 1998;393:702-705.
} 
-2 Poorkaj P, Bird TD, Wijsman E, Nemens E, Garruto RM, Anderson L, Andreadis A, Wiederholt WC, Raskind M, Schellenberg GD: Tau is a candidate gene for chromosome 17 frontotemporal dementia. Ann Neurol 1998;43:815-825.

-3 Spillantini MG, Murrell JR, Goedert M, Farlow MR, Klug A, Ghetti B: Mutation in the tau gene in familial multiple system tauopathy with presenile dementia. Proc Natl Acad Sci USA 1998;95:7737-7741.

4 van Swieten J, Spillantini MG: Hereditary frontotemporal dementia caused by Tau gene mutations. Brain Pathol 2007;17:63-73.

$\checkmark 5$ Dickson DW, Rademakers R, Hutton ML: Progressive supranuclear palsy: pathology and genetics. Brain Pathol 2007;17:74-82.

-6 Delisle MB, Murrell JR, Richardson R, Trofatter JA, Rascol O, Soulages X, Mohr M, Calvas $\mathrm{P}$, Ghetti $\mathrm{B}$ : A mutation at codon 279 $(\mathrm{N} 279 \mathrm{~K})$ in exon 10 of the Tau gene causes a tauopathy with dementia and supranuclear palsy. Acta Neuropathol 1999;98:62-77.

7 Stanford PM, Halliday GM, Brooks WS, Kwok JB, Storey CE, Creasey H, Morris JG, Fulham MJ, Schofield PR: Progressive supranuclear palsy pathology caused by a novel silent mutation in exon 10 of the tau gene: expansion of the disease phenotype caused by tau gene mutations. Brain 2000;123(pt 5):880-893.

8 Poorkaj P, Muma NA, Zhukareva V, Cochran EJ, Shannon KM, Hurtig H, Koller WC, Bird TD, Trojanowski JQ, Lee VM, Schellenberg GD: An R5L tau mutation in a subject with a progressive supranuclear palsy phenotype. Ann Neurol 2002;52:511-516.
-9 Tsuboi Y, Uitti RJ, Delisle MB, Ferreira JJ, Brefel-Courbon C, Rascol O, Ghetti B, Murrell JR, Hutton M, Baker M, Wszolek ZK: Clinical features and disease haplotypes of individuals with the $\mathrm{N} 279 \mathrm{~K}$ tau gene mutation: a comparison of the pallidopontonigral degeneration kindred and a French family. Arch Neurol 2002;59:943-950.

10 Morris HR, Osaki Y, Holton J, Lees AJ, Wood NW, Revesz T, Quinn N: Tau exon $10+16$ mutation FTDP-17 presenting clinically as sporadic young-onset PSP. Neurology 2003; 61:102-104.

-11 Rossi G, Gasparoli E, Pasquali C, di Fede G, Testa D, Albanese A, Bracco F, Tagliavini F: Progressive supranuclear palsy and Parkinson's disease in a family with a new mutation in the tau gene. Ann Neurol 2004;55:448.

12 Ros R, Thobois S, Streichenberger N, Kopp N, Sánchez MP, Pérez M, Hoenicka J, Avila J, Honnorat J, de Yébenes JG: A new mutation of the tau gene, G303V, in early-onset familial progressive supranuclear palsy. Arch Neurol 2005;62:1444-1450.

13 Spina S, Farlow MR, Unverzagt FW, Kareken DA, Murrell JR, Fraser G, Epperson F, Crowther RA, Spillantini MG, Goedert M, Ghetti B: The tauopathy associated with mutation +3 in intron 10 of Tau: characterization of the MSTD family. Brain 2008;131(pt 1):72-89.

14 Kaat LD, Boon AJ, Azmani A, Kamphorst W, Breteler MM, Anar B, Heutink P, van Swieten JC: Familial aggregation of parkinsonism in progressive supranuclear palsy. Neurology 2009;73:98-105.
15 Rohrer JD, Guerreiro R, Vandrovcova J, Uphill J, Reiman D, Beck J, Isaacs AM, Authier A, Ferrari R, Fox NC, Mackenzie IR, Warren JD, de Silva R, Holton J, Revesz T, Hardy J, Mead S, Rossor MN: The heritability and genetics of frontotemporal lobar degeneration. Neurology 2009;73:1451-1456.

- 16 D’Souza I, Poorkaj P, Hong M, Nochlin D, Lee VM, Bird TD, Schellenberg GD: Missense and silent tau gene mutations cause frontotemporal dementia with parkinsonism-chromosome 17 type, by affecting multiple alternative RNA splicing regulatory elements. Proc Natl Acad Sci USA 1999;96: 5598-5603.

17 Poorkaj P, Grossman M, Steinbart E, Payami $\mathrm{H}$, Sadovnick A, Nochlin D, Tabira T, Trojanowski JQ, Borson S, Galasko D, Reich S, Quinn B, Schellenberg G, Bird TD: Frequency of tau gene mutations in familial and sporadic cases of non-Alzheimer dementia. Arch Neurol 2001;58:383-387.

18 D'Souza I, Schellenberg GD: Regulation of tau isoform expression and dementia. Biochim Biophys Acta 2005;1739:104-115.

19 Pastor P, Pastor E, Carnero C, Vela R, Garcia T, Amer G, Tolosa E, Oliva R: Familial atypical progressive supranuclear palsy associated with homozygosity for the delN296 mutation in the tau gene. Ann Neurol 2001;49: 263-267.

20 Wszolek ZK, Tsuboi Y, Uitti RJ, Reed L, Hutton ML, Dickson DW: Progressive supranuclear palsy as a disease phenotype caused by the S305S tau gene mutation. Brain 2001; 124(pt 8):1666-1670 